\title{
Capacities of the Army of the Czech Republic in Rescue and Liquidation Work in the Regions of the Czech Republic
}

\author{
Irena TUŠER ${ }^{1}$, Jiří JÁNSKÝ² \\ ${ }^{1}$ AMBIS College, Department of Security and Law; Lindnerova 1, 18000 Prague, Czech Republic \\ ${ }^{2}$ University of Defence, Brno, Faculty of Military Technology; Kounicova 65, 66210 Brno, Czech Republic
}

E-mails: ${ }^{1}$ irena.tuser@ambis.cz; ${ }^{2}$ jiri.jansky@unob.cz

\begin{abstract}
The military forces and means are used to fulfill humanitarian tasks of civil protection and to fulfill the tasks [of the Police of the Czech Republic in serious situations endangering lives, health, property, or the environment. If the responsible administrative authorities, territorial self-governing bodies, fire protection authorities, or military rescue units are unable to provide rescue work or liquidate the consequences of a disaster on their own, the military is called. In addition to conventional defense tasks, it is therefore necessary to ensure the overall preparation of all components of the army for the performance of other tasks in cooperation with civilian authorities in their own territory. The paper focuses on the issues of civil-military cooperation, active advances and current capabilities of the Army of the Czech Republic in providing cooperation in rescue and liquidation work in the regions of the Czech Republic. The analysis of this issue identified the key aspects and for the subsequent determination of the evaluation criteria, the multi-criteria method was applied. The authors suggest certain procedures for updating the current situation that could be applicable in practice.
\end{abstract}

KEY WORDS: Active reserves, army, civil-military cooperation, integrated rescue system, defense, forces and means, population protection, rescue and liquidation work

\section{Introduction}

In a broader sense, the protection of the population in the Czech Republic means the preparation for emergency situations, and the implementation of rescue and liquidation work $[1,2]$. Responsibility for the implementation of measures to protect the population is transferred to state authorities, local authorities, legal entities, and natural persons engaged in business [3]. If the implementation of the planned measures carried out by the primary units of the Integrated Rescue System (IRS) is insufficient in capacity, other IRS units, including the Army of the Czech Republic (ACR), are called in to deal with a large-scale emergency or crisis situation.

The use of military forces and resources occurs in serious situations endangering lives, health or the environment, in the performance of humanitarian tasks of civil protection, and in the performance of tasks of the Police of the Czech Republic $[4,5]$. In addition to the standard defense tasks, it is therefore necessary to ensure the overall preparation of all units of the army for the performance of other tasks in cooperation with civilian authorities within its national territory.

The paper therefore focuses on the issue of civil-military cooperation, active reserves and the current capabilities of the Army of the Czech Republic in providing cooperation in rescue and liquidation work in the regions of the Czech Republic (CR).

The aim of the paper is to analyze the current capabilities of the Army of the Czech Republic (ACR) in providing cooperation in rescue and liquidation work in the regions of the Czech Republic with a subsequent proposal of measures.

At present, the presented topic is more than current, not only from the point of view of civil-military collaboration within the framework of cooperation in rescue and liquidation work in crisis situations. The analysis of the current capabilities of the ACR is presently very urgent in the event of a global pandemic of the covid-19 disease and the associated mass deployment of forces and resources (F\&R) of primary and other units of the IRS [6].

\section{Methodology and used Methods}

The ACR construction concept until 2030 does not expect any further development of the capacity of civil protection forces within the Ministry of Defence (ACR construction concept, 2019). However, both experience in

${ }^{1}$ Corresponding author. Tel.: +420608950284

E-mail address: irena.tuser@ambis.cz 
managing the consequences of floods and other natural disasters, and experience in managing the consequences of the covid-19 pandemic have shown that armed forces around the world have an irreplaceable position in dealing with nonmilitary crises [7-10]. For this reason, it is essential that modern armed forces in the Czech Republic and in the world have a type of force whose primary activity is precisely to prepare for crisis situations of a non-military nature. In modern history, there has never been a situation where the Czech Republic would be threatened by military and nonmilitary threats at the same time, but it is precisely for these cases that it is necessary to have types of forces designed to defend the territory and other types of forces that will perform humanitarian tasks of civil protection.

The research part of the article is focused on ascertaining the current capabilities of the ACR in providing cooperation in rescue and liquidation work in the regions of the Czech Republic.

To determine the current situation, the method of multicriteria evaluation of the ACR capabilities was chosen. Therefore it was necessary to first establish criteria according to which the current situation will be assessed. Simultaneously with the definition of criteria, their indicators had to be specified to determine the degree of fulfillment of these criteria (Švarcová, I., 2017). Sub-questions had to be created for individual indicators, to which the respondents answered in a questionnaire survey in the form of allocating points from the evaluation scale 5 - 1 . The formulated sub-questions were the basis for obtaining information on the fulfillment of individual indicators.

The determination of criteria and their indicators was performed on the basis of brainstorming with experts working in the field, ie. with members of the ACR at the tactical, operational and strategic level of command of the ACR. In total, there were 20 experts. Within the brainstorming, the four most important criteria and their indicators were determined, which were used to determine the current state of the capabilities of the ACR. The results of brainstorming with these members of the ACR - determination of criteria and their indicators are shown in Table 1.

Table 1.

Criteria and indicators

\begin{tabular}{|c|c|}
\hline Criterion & Indicators for fulfilling the criterion (and their marking) \\
\hline $\begin{array}{l}\text { Criterion A } \\
\text { Human resources }\end{array}$ & $\begin{array}{l}\text { - } \quad \text { Quantity of allocated forces (marked } I_{1}^{A} \text { ) } \\
\text { - } \quad \text { Preparedness of allocated forces to perform tasks in favor of IRS } \\
\text { (quality) (marked } I_{2}^{A} \text { ) } \\
\text { - } \quad \text { Preparedness of control officers of allocated forces (marked } I_{3}^{A} \text { ) } \\
\end{array}$ \\
\hline $\begin{array}{l}\quad \frac{\text { Criterion B }}{\text { Technical security of }} \\
\text { allocated forces }\end{array}$ & $\begin{array}{ll}\text { - } & \text { Transport equipment }\left(\operatorname{marked} l_{1}^{\bar{B}}\right) \\
- & \text { Special equipment }\left(\operatorname{marked} l_{2}^{\bar{B}}\right) \\
\text { - } & \text { Material and logistical support }\left(\operatorname{marked} l_{3}^{\bar{B}}\right)\end{array}$ \\
\hline $\begin{array}{l}\text { Criterion } \mathbf{C} \\
\text { Command and control of } \\
\text { allocated forces }\end{array}$ & $\begin{array}{l}\text { - } \quad \text { Command and control system (marked } I_{1}^{C} \text { ) } \\
\left.\text { - } \quad \text { Metification of ACR units and facilities (marked } I_{2}^{c}\right) \\
\end{array}$ \\
\hline $\begin{array}{l}\text { Criterion D } \\
\text { Planning for the } \\
\text { deployment of F\&R of the } \\
\text { ACR }\end{array}$ & $\begin{array}{l}\text { - } \quad \text { Planning and management documentation }\left(\operatorname{marked} I_{1}^{D}\right) \\
\left.\text { - Standardized operating procedures (marked } I_{2}^{D}\right)\end{array}$ \\
\hline
\end{tabular}

A questionnaire survey (allocation of points to individual sub-questions) was conducted at military units in all regions of the Czech Republic and at all organizational units of the Ministry of Defence with nationwide authority, which directly participated in securing measures related to the declaration of a state of emergency due to reduction and management of the consequences of the covid-19 pandemic. Further questionnaire surveys were conducted at the Operations Command, which currently manages operations in the Czech Republic designed to manage the consequences of the pandemic, and with members of the Ministry of Defence participating in the activities of the strategic command and control group. A total of 21 respondents cooperated.

The evaluation (scoring) scale of the fulfillment of indicators was determined for the questionnaire survey as follows:

5 points $=$ completely fulfilled

4 points $=$ fulfilled to a greater extent

3 points $=$ moderately fulfilled

2 points $=$ largely unfulfilled

1 point $=$ not fulfilled at all $[11,12]$. 
Unfortunately, the limiting factor for the scope of the entire research survey was the prohibition of personal contact within the Ministry of Defence, issued as a measure to prevent the spread of the covid-19 epidemic. However, personal contact with the respondents was necessary for the correctness and completeness of the questionnaire, so it was possible to obtain only a limited number of respondents at that time.

The degree of fulfillment of indicators according to individual respondents was calculated as the sum of points awarded according to the above-mentioned evaluation system, which was subsequently divided by the maximum possible number of points for the given indicator. The fulfillment of the criteria determined by means of a questionnaire survey therefore takes values in the interval $<0,1>$. For the purposes of further procedure, it is necessary to average these values. The average values of the fulfillment of the indicators are given in Table 2 below.

Table 2.

Fulfillment of indicators

\begin{tabular}{|c|c|c|}
\hline Criterion & Indicators for the fulfillment of the criterion & Fulfillment of the indicators \\
\cline { 2 - 3 } & $I_{1}^{A}$ & $k_{1}^{A} k_{1}^{A}=0,249$ \\
\cline { 2 - 3 } & $I_{2}^{A}$ & $k_{2}^{A} k_{2}^{A}=0,207$ \\
\hline \multirow{4}{*}{$\mathrm{B}$} & $I_{3}^{A}$ & $k_{3}^{A} k_{3}^{A}=0,232$ \\
\cline { 2 - 3 } & $I_{1}^{B}$ & $k_{1}^{B} k_{1}^{B}=0,241$ \\
\cline { 2 - 3 } & $I_{2}^{B}$ & $k_{2}^{B} k_{2}^{B}=0,224$ \\
\hline \multirow{3}{*}{$\mathrm{C}$} & $I_{3}^{B}$ & $k_{3}^{B} k_{3}^{B}=0,229$ \\
\cline { 2 - 3 } & $I_{1}^{C}$ & $k_{1}^{C} k_{1}^{C}=0,276$ \\
\cline { 2 - 3 } & $I_{2}^{C}$ & $k_{2}^{C} k_{2}^{C}=0,281$ \\
\hline \multirow{2}{*}{$\mathrm{D}$} & $I_{3}^{C}$ & $k_{3}^{C} k_{3}^{C}=0,224$ \\
\cline { 2 - 3 } & $I_{1}^{D}$ & $k_{1}^{D} k_{1}^{D}=0,398$ \\
\cline { 2 - 3 } & $I_{3}^{D}$ & $k_{2}^{D} k_{2}^{D}=0,367$ \\
\hline
\end{tabular}

The following intervals were chosen to determine the value of meeting the individual criteria:

- 1 - 0,9 - fulfilled;

- $0,89-0,63$ - fulfilled with restriction;

- $0,62-0-$ unfulfilled.

The resulting fulfillment of the set criteria is shown in Table 3.

Table 3.

Total fulfillment of criteria

\begin{tabular}{|c|c|c|}
\hline Criterion & Total fulfillment & Evaluation \\
\hline A & 0,688 & Fulfilled with restriction \\
\hline B & 0,694 & Fulfilled with restriction \\
\hline C & 0,781 & Fulfilled with restriction \\
\hline D & 0,765 & Fulfilled with restriction \\
\hline
\end{tabular}

\section{Results and Suggestions}

The research shows that all criteria are only partially met. A multi-criteria evaluation and a questionnaire survey showed that criteria A (Human Resources) and B (Technical Security of allocated Forces) are assigned the highest importance by respondents, but at the same time these criteria are met just above the threshold set for the criterion. The lower fulfillment of criteria A and B could be negatively affected by a higher number of respondents from the tactical level of ACR command and control, who have allocated F\&R in direct subordination and therefore have a better overview of the real state of manpower and equipment than respondents from operational and strategic level, who only report on the numbers of equipment and manpower. Criteria C (Command and Control of Allocated Forces) and D (Planning for the Deployment of the F\&R of the ACR) were assigned the lowest importance by the respondents. Despite this, these criteria, compared to criteria A and B, are more fulfilled by almost one point. The 
values obtained by the research show that managers at all levels of command and control of the ACR see room for improvement in all areas examined in the research part of this work. For possible follow-up research, it would be appropriate to obtain a wider sample of respondents from all levels of ACR command and control, and also from ACR members who are not at management positions, at least one year away from current measures to manage the consequences of the covid-19 pandemic $[13,14]$.

In the initial phase of the outbreak of the covid-19 pandemic, the shortcomings of the current system of providing cooperation of the ACR to the primary units of the IRS and other eligible applicants for providing cooperation were revealed. These shortcomings are mainly caused by inconsistent operational procedures within all IRS units, and the inconsistent way of requiring the cooperation of the F\&R of the ACR, which are not specified in the cooperation agreements. In order to eliminate these shortcomings, the setting of information flows, the determination of specific responsible persons, the areas of responsibility of these persons, and a uniform system of receiving and evaluating requirements are crucial. It is necessary to specify the system of requiring F\&R of the ACR, which are not listed in the cooperation agreements, and to train all eligible applicants in this system. Due to the large scope of operations coordinated by the Ministry of the Interior through the Operational and Information Center (OIC) of the IRS, the ACR could not comply with all requests for the provision of the F\&R of the ACR, which were received in a different way than through the relevant OIC of the IRS. The deployment of these F\&R of the ACR therefore took place only if the request was forwarded to the relevant OPIS. This then analyzed the request, and only then passed it on to the Permanent Shift of the Joint Operations Center of the Operations Command (PS JOC OC). This caused unnecessary delays in the deployment of the required F\&R of the ACR. The inconsistent system of requiring F\&R of the ACR also caused problems in securing transport by military means. Due to the current non-uniform system of requiring F\&R of the ACR (lack of harmonizing standards for civil-military cooperation), and the absence of a system of time standards, the ACR was not able to meet some requirements in extreme cases. The IRS has F\&R set up in a 24/7 mode, and in connection with this mode, these intervention units also plan and perform tasks (very often ad-hoc). The ACR, except for workplaces with non-stop service, maintains the daily working time regime, therefore ad-hoc activation of the F\&R of the ACR is not possible. To improve the described situation, it is proposed to create a working group composed of members from the primary and secondary units of the IRS, and representatives of the regions (local self-governments). Their output should then be the standardization and optimization of processes from the request of the F\&R of the ACR at the regional level to the actual deployment of all F\&R units of the IRS and the $\mathrm{ACR}$. It is also necessary to amend legislative measures to remedy the current inconsistency.

Another part of this measure is a legislative amendment to the Public Procurement Act, or related legislation or a decree laying down precise rules for the acquisition of property and services in crisis situations. It is necessary to specify exactly who may award public contracts in the event of a crisis, who may be the supplier of materials or services, what may be purchased, the financial and time frame of those contracts, the purpose for which public contracts may be awarded, and the exact procedure for how to proceed with the acquisition of property and services by public tender or by directly contacting the supplier during a state of emergency [15-18].

To increase the efficiency of providing co-operation within the IRS or in conducting operations for the benefit of the IRS in the Czech Republic, it is crucial that the ACR has its own Operations and Information Center modeled on the Police of the Czech Republic (PCR) or the Fire and Rescue Service (FRS). Currently, some of the functions that, according to the authors, should be performed by the OIC of the ACR, are held by the PS JOC OC, but this is not the main type of activity and the PS JOC OC primarily performs other tasks. Likewise, the main command post of the Armed Forces of the Czech Republic cannot fulfill the tasks of coordination of the F\&R of the ACR deployed in operations for the benefit of the IRS and regions of the Czech Republic, because it is intended to ensure the command and control of the Armed Forces of the Czech Republic in the event of a military threat to the state. In the event of a simultaneous emergence and duration of a military and non-military crisis situation, it is crucial that the deployment and management of the F\&R of the ACR be carried out through two different headquarters, determined by the nature of the crisis situation. Activation of the F\&R of the ACR for non-military operations would be implemented through the OIC of the ACR. Activation of the F\&R of the ACR for a military operation will be managed through the Main Command of the Armed Forces of the Czech Republic. These two elements of command and control should then be subordinated to the joint operational planning group (operational level of command) or the strategic operational planning group of the ACR command and control.

\section{Conclusions}

The ACR primarily performs tasks related to ensuring external security in the event of a military crisis. The ACR is established for this activity, and preparation for this type of threat is its main task in time of peace. The F\&R of the ACR is involved in the management of crisis and emergency situations of a non-military nature in the regions of the Czech Republic as a secondary unit of the IRS upon request by eligible applicants, according to concluded 
cooperation agreements or regulations of the Government of the Czech Republic [19-22]. Until 2013, these tasks of civil protection in non-military crisis situations were performed by military rescue services. After they were cancelled, the ACR detachments included in the Central Alarm Plan of the Czech Republic are allocated to perform these tasks on the basis of an agreement on assistance on request. However, in times of peace, the detachments are preparing mainly to perform tasks in the event of a military crisis. In addition to rescue and liquidation work, the selected F\&R of the ACR participate in the performance of internal security tasks in cooperation with the Police of the Czech Republic, and provide air medical rescue service, and air search and rescue service. Whether professional soldiers of the Army of the Czech Republic or members of the active reserve, who voluntarily enlisted in the military service, both participated in the management of any territorially extensive crisis situation in the Czech Republic in the modern history of the country. Specialized ACR detachments are usually activated in cases where the primary units of the IRS are exhausted by managing the consequences of crisis situations or in the event of an emergency situation, when it is necessary to use the capabilities of specialized ACR units that the IRS does not have.

For follow-up research, it would be appropriate to conduct a questionnaire survey with a wider sample of respondents at all levels of ACR command and control, and to start research with the primary units of the IRS and in the regions of the Czech Republic with eligible applicants for ACR cooperation. The aim of the follow-up research on the primary units of the IRS and the regions of the Czech Republic should be to specify the real needs and requirements of all participants in crisis management for the F\&R of the ACR in crisis management at the regional level. Part of the follow-up research at the Army of the Czech Republic is intended to complete the findings obtained by research conducted for the purposes of this paper.

\section{Acknowledgements}

Irena Tušer thanks her AMBIS College, Prague and Jiří Jánský thanks for support from the project DZRO K217, supported by the Ministry of Defence in the Czech Republic.

\section{References}

1. Talhofer, V., Hošková-Mayerová, Š. Method of selecting a decontamination site deployment for chemical accident consequences elimination: application of multi-criterial analysis. ISPRS International journal of geoinformation, 2019, 8(4), p. 1-21. https://doi.org/10.3390/ijgi8040171

2. Otrisal, P., Obsel, V., Buk, J., Svorc, L. Preparation of filtration sorptive materials from nanofibers, Bicofibers, and Textile Adsorbents without Binders Employment. Nanomaterials, 2018, 8(8), pp. 564. https://doi.org/10.3390/ nano8080564

3. Procházka, J., Procházková D. Problems of mobile risks in territory. Safety and Reliability - Safe Societies in a Changing World. Taylor \& Francis Group, 2018, pp. 1783. https://doi.org/10.1201/9781351174664-223

4. Navrátil, J., Sadovská, V., Švarcová, I. Health risk assessment of combustion products from simulated residential fire, Studies in Systems, Decision and Control 104, 2019. p. 15-23, https://doi.org/10.1007/978-3-319-54819-7_2

5. Svarcova, I., Hoskova-Mayerova, S., Navratil, J. Crisis management and education in health, European Proceedings of Social and Behavioural Sciences, 2016,(16), p. 255-261. https://doi.org/10.15405/epsbs.2016.11.26

6. Štěpánek, B., Otř́sal, P. The development and establishment process of centres of excellence in north atlantic organization. In: Conference proceedings of the $5^{\text {th }}$ International Conference on Advances and Systems Research ECNSI-2011 „Special Focus Symposium on $3^{\text {rd }}$ IKS: Information and Knowledge Systems“. V. Šimovic, L. Buřita, P. Hrůza (eds). Zagreb. 2011. p. 131-135.

7. Malachova, H., Oulehlova, A., Kincl, P. SIMEX simulation tool - "accident" crisis scenario and crisis management entities' exercise, In: Communication and Information Technologies (KIT), Barath, J., Dedera, L., Ockay, M. (eds.), Slovakia 2017. p. 83-89. https://doi.org//10.23919/KIT.2017.8109453.

8. Oulehlova, A. Malachova, H., Rezac, D. Use of simulation in cooperation training of critical infrastructure entities, In: Distance Learning, Simulation and Communication 'DLSC 2015', 2015. p. 103-112.

9. Oulehlova, A., Malachova, H., Rezac, D. Risks evaluation in preparation of crisis management exercise, In: Distance Learning, Simulation and Communication 'DLSC 2017', 2017, p. 143-153.

10. Potůček, R. Life cycle of the crisis situation threat and its various models, Studies in Systems, Decision and Control 208, 2020. p. 443-461, https://doi.org/10.1007/978-3-030-18593-0_32

11. Tušer, I., Navrátil, J. Evaluation criteria of preparedness for emergency events within the emergency medical services, Studies in Systems, Decision and Control 208. p. 463-472, 2020, https://doi.org/10.1007/978-3-03018593-0_33

12. Svarcova, I., Ptacek, B., Navratil, J. Psychological intervention as support in disaster preparedness, In: Crisis Management and Solution of the Crisis Situations 2015. p. 317-320, 2015. 
13. Hoskova-Mayerova S. (2016) Education and training in crisis management, The European Proceedings of Social \& Behavioural Sciences EpSBS, Volume XVI, p. 849-856. http://dx.doi.org/10.15405/epsbs.2016.11.87

14. Adamoniene, R. Management presumptions and possibilities of human resources formation, Bekesiene S., Hoskova-Mayerova S. (eds.), Challenges to National Defence in Contemporary Geopolitical Situation (CNDCGS' 2018), 2018. p. 157-166.

15. Kudlak, A., Urban, R., Hoskova-Mayerova, S. Determination of the financial minimum in a municipal budget to deal with crisis situations. Soft Computing, 2020, 24(12), p. 8607-8618. https://doi.org/10.1007/s00500-01904527-w.

16. Neubauer, J. Odehnal, J. ARDL models of military spending and its security and economic determinants, In: Bekesiene, Hoskova-Mayerova (Eds.), Challenges to National Defence in Contemporary Geopolitical Situation (CNDCGS' 2018), 2018. p. 109-114.

17. Ministry of Defence, Development, Concepts and doctrine centre. joint doctrine publication 3-52. (JDP 3-52) Disaster Relief Operations Overseas: the Military Contribution. (3rd Edition), 2016.

18. https://assets.publishing.service.gov.uk/government/uploads/system/uploads/attachment_data/file/574033/ doctrine_uk_dro_jdp_3_52.pdf

19. NATO civil emergency planning euro-atlantic disaster response coordination centre. nato's role in disaster assistance. (Second Edition), 2001. https://www.nato.int/eadrcc/mcda-e.pdf

20. Bekesiene, S., Hošková-Mayerová, Š. Decision tree-based classification model for identification of effective leadership indicators. J. Math. Fund. Sci, 2018, 50(2), p. 121-141. Doi:10.5614/j.math.fund.sci.2018.50.2.2

21. Otř́sal, P. Florus, S. Současnost a perspektivy fyzické a kolektivní ochrany proti účinkům toxických látek. Chem. Listy, 2014, 108 (12), p. 1168-1171. (In Czech)

22. Florus, S., Otř́śsal, P. Vybrané metody studia chemické odolnosti izolačních ochranných fólií pro bojové chemické látky. Chem. Listy, 2014, 108(9), p. 838-842. (In Czech)

23. Svarcova, I., Hoskova-Mayerova S., Navratil, J. Crisis Management and Education in Health, The European Proceedings of Social \& Behavioural Sciences EpSBS, Volume XVI, 2016, p. 255-261. http://dx.doi.org/10.15405/ epsbs.2016.11.26 